\title{
RESIDUAL EFFECT OF CERTAIN COPPER FUNGICIDES USED IN CONTROLLING DOWNY MILDEW OF LETTUCE
}

\author{
ALKOLALY, ASMAA. M. ${ }^{1}$, SHEREEN. E. M. EL-NAHAS ${ }^{1}$, T. A.ABDEL-RAHMAN ${ }^{2}$
}

1. Plant Pathology Research Institute, ARC, Giza, Egypt

2. Central Agricultural Pesticides Laboratory, ARC, Dokki, Giza, Egypt.

(Manuscript received 11 August 2016)

\begin{abstract}
$\mathrm{T}$ he fungicidal residues of certain copper fungicides, i.e. copper oxychloride, copper hydroxide and Copper salts of fatty and rosin acids used against downy mildew in lettuce were studied. Data showed the occurrence of $\mathrm{Cu}$ residues in the plant, at different values according to the forms and rates used. Copper compounds residues were digested from lettuce plants samples then the residues were determined by microwave plasma atomic emission spectrometry. Results indicated that the pre harvest interval (PHI) for lettuce plants were 1, 3 and 4 days for copper salts, copper hydroxide and copper oxychloride, respectively.

Key words: copper fungicide, Lactuca sativa, Microwave, plasma atomic, dissipation, residue
\end{abstract}

\section{INTRODUCTION}

Lactuca sativa L. (Asteraceae) is one of the most important leafy vegetables. It is almost exclusively used fresh in salads, but some forms are also cooked (Lebeda et al., 2007). Lettuce is produced commercially in many countries worldwide and is also widely grown as a vegetable in home gardens (Rubatzky and Yamaguchi, 1997). It is especially important as a commercial crop in Asia, North and Central America, and Europe. China, U.S.A., Spain, Italy, India and Japan are among the world's largest producers (Lebeda et al., 2007). Lettuce downy mildew, caused by Bremia lactucae, is the most important disease affecting lettuce worldwide. It has a direct effect on yield and quality, since it affects the marketable portion of the crop. Although yield losses in the field at harvest may be substantial, downy mildew's impact is often accentuated by significant postharvest losses that occur during transit or storage.

Pesticides played an inevitable role in modern agriculture. Rising concern about food safety and environmental impact has led to increasing number of studies on the impact of pesticide residues in agricultural products consumed by humans. With the intensive, indiscriminate and injudicious use, pesticides have resulted in widespread contamination of food and feed. This is related to poor handling practices and the use of more toxic insecticides by farmers (APHA, 2005). As a consequence, governments and international organizations have established maximum residue limits 
(MRLs) and pre-harvest intervals (PHI) for fruits and vegetables, as the time between the last pesticide spray and harvest of the treated crops, (EPA, 2015).

Copper-based preparations have been used for over 200 years to control fungi and bacterial diseases in cultivated plants. Their use became widespread after the accidental discovery of Bordeaux mixture in 1880 (Zwieten et al., 2007). At the time, winegrowers in the Bordeaux wine region were using a mixture of copper sulphate and lime to deter passersby from eating the grapes, Millardet noted that these grapes did not show any signs of downy mildew; and confirmed that this mixture controlled this disease at relatively low cost. Therefore, Bordeaux mixture became the first fungicide to be used on a large scale worldwide (Schneiderhan, 1933).

The present study examined the behaviour of three commercial formulations of copper compounds on lettuce plants, and determined residual behaviour, preharvest intervals and half-lives in/on lettuce plants.

\section{MATERIALS AND METHODS}

\section{Pots experiment}

Transplants of lettuce (cv. Cabucha) were used in the experiment. The experiment was carried out by using $25 \mathrm{~cm}$-clay pots at Plant Pathology Research Institute, Giza during 2015 growing season. When the plants reached 25 days old and before the natural infection by downy mildew was established, the plants were sprayed 3 times with each of the tested fungicides at 10 days intervals. Three different fungicides were used (Table 1) and 15 Pots were used for each fungicide. Disease severity was estimated 10 days after the last spray. Disease severity data were used to calculate the fungicidal efficacy.

\section{Fungicides used: -}

Table 1. Copper fungicides used in study

\begin{tabular}{|c|c|c|c|c|}
\hline \multicolumn{4}{|c|}{ Fungicides } & \multirow{2}{*}{$\begin{array}{l}\text { Recommended } \\
\text { Rate/ } 100 \mathrm{~L} \text { water }\end{array}$} \\
\hline Common name & Formulation type & Trade name & Structure & \\
\hline $\begin{array}{l}\text { Copper salts of } \\
\text { fatty and rosin } \\
\text { acids }\end{array}$ & $5 \% \mathrm{EC}$ & Labrador & $\mathrm{C}_{40} \mathrm{H}_{58} \mathrm{CuO}_{4}$ & $200 \mathrm{~cm}^{3}$ \\
\hline $\begin{array}{l}\text { Copper } \\
\text { oxychloride }\end{array}$ & $50 \% \mathrm{WP}$ & Adwecopper & $\mathrm{CuCl}_{2} .3 \mathrm{Cu}(\mathrm{OH})_{2}$ & $250 \mathrm{gm}$ \\
\hline $\begin{array}{l}\text { Copper } \\
\text { hydroxide }\end{array}$ & $50 \% \mathrm{WP}$ & Flacopper & $\mathrm{Cu}(\mathrm{OH})_{2}$ & $250 \mathrm{gm}$ \\
\hline
\end{tabular}




\section{Sample:}

Sampling was performed by randomly collecting $50 \mathrm{gm}$ representative samples of lettuce leaves according to the FAO/WHO recommendations (1986). Three replicate samples were collected from leaves of the treated plant after each spray. Samples were taken $1 \mathrm{~h}, 3$ and 10 days after $1^{\text {st }}$ and $2^{\text {nd }}$ spray, while in the $3^{\text {rd }}$ spray was an additional sample was taken after 5 days. The plants were sprayed three times with fungicides at 10 days interval at the recommended rates of each. Collected samples were stored in clean polyethylene bags at $-20^{\circ} \mathrm{C}$.

\section{Sample preparation:}

Microwave digestion was used to prepare the lettuce plant samples. Ten $\mathrm{ml}$ of concentrated $\mathrm{HNO}_{3}$ was added to accurately weighed $0.5 \mathrm{~g}$ of the sample. A preloaded method for the MARS6 (CEM, Corporation, USA) microwave was used to digest the samples. Once cooled, the solution was diluted quantitatively to $25 \mathrm{ml}$ with ultrapure water. The microwave digestion parameters was made at $210^{\circ} \mathrm{C}, 800$ PSI for ramp $21 \mathrm{~min}$, hold $15 \mathrm{~min}$, Power of 400- $1800 \mathrm{~W}$. The instrument operated in a fast sequential mode and featured a Pettier-cooled CCD detector. Background and spectral interferences could be simultaneously corrected easily and accurately using Agilent's MP Expert software. Copper was monitored at wavelengths 324 $752 \mathrm{~nm}$, and calibration range $0-0.5 \mu \mathrm{g} \mathrm{ml}^{-1}$.

The average recoveries ranged between $91.4 \%$ and $96 \%$, and LOD was $0.005 \mathrm{mg} \mathrm{kg}^{-1}$. LOD were determined on samples at spiking levels $0.01-0.05 \mu \mathrm{g} \mathrm{ml}^{-1}$ from the fungicide standard. Correlation Coefficient was 0.99915

Table 2. Microwave Plasma Atomic Emission Parameters

\begin{tabular}{|l|l|}
\hline \multicolumn{1}{|c|}{ Parameter } & \multicolumn{1}{c|}{ Value } \\
\hline Replicates & 3 \\
\hline Pump rate & $15 \mathrm{rpm}$ \\
\hline Sample uptake delay & 15 seconds \\
\hline Rinse time & 30 seconds \\
\hline Stabilization time & 15 second \\
\hline Fast Pump during Uptake and Rinse & On (80 rpm) \\
\hline Nebulizer & One Neb \\
\hline Spray chamber & Double pass cyclonic \\
\hline $\begin{array}{l}\text { Auto sampler } \\
\text { Sample pump tubing } \\
\text { Waste pump tubing }\end{array}$ & $\begin{array}{l}\text { Agilent SPS 3 } \\
\text { Brange/green } \\
\text { Blue/blue }\end{array}$ \\
\hline
\end{tabular}




\section{RESULTS AND DISCUSSION}

Results in Table (3) showed that copper oxychloride showed higher residue levels when compared with copper salts, copper hydroxide at most intervals. The initial deposits found after one hour from the first spray was $107 \mathrm{mg} \mathrm{kg}^{-1}$. After the second and third spray, the initial deposits were 108.7 and $130 \mathrm{mg} \mathrm{kg}^{-1}$, respectively. The residue levels were decreased to $36.5 \mathrm{mg} \mathrm{kg}^{-1}$ showing the percentage of loss was $65.88 \%$ after 10 days from the first spray. At the same intervals of the second and third spray, the residue levels were decreased to 31 and $26 \mathrm{mg} \mathrm{kg}^{-1}$ showing the percentage loss of 71.48 and $80 \%$, respectively. The estimated half-life ( $\left.t_{0.5}\right)$ value was 8 days after the first spray, while after the third spray it was 6.6 days.

The initial deposit of copper hydroxide after the first spray was $100 \mathrm{mg} \mathrm{kg}^{-1}$. After the second and third spray, the initial deposits were 106 and $127 \mathrm{mg} \mathrm{kg}^{-1}$, respectively. The residue levels were decreased to $33.3 \mathrm{mg} \mathrm{kg}{ }^{-1}$ showing the percentage loss $66.7 \%$ after 10 days. At the same intervals of the second and third spray, the residue levels were decreased to 34 and $23 \mathrm{mg} \mathrm{kg}^{-1}$ showing the percentage loss of 67.92 and $97.17 \%$, respectively. The estimated half-life ( $\left.t_{0.5}\right)$ approximate value was 7.8 days after the first spray it while after the third spray was 5.8 days.

Copper salts found after one hour from the first spray was $89 \mathrm{mg} \mathrm{kg}^{-1}$. After the second and third spray, the initial deposits were 95.5 and $105 \mathrm{mg} \mathrm{kg}^{-1}$, respectively. The residue levels were decreased to $23 \mathrm{mg} \mathrm{kg}^{-1}$ showing the percentage loss $74.15 \%$ after 10 days. At the same intervals of the second and third spray, the residue levels were decreased to 30 and $20 \mathrm{mg} \mathrm{kg}^{-1}$ showing the percentage of loss were 68.58 and $80.95 \%$, respectively. The estimated half-life ( $\left.t_{0.5}\right)$ approximate value was 6.8 days after the first spray, while after the third spray was 6.3 days.

Fungicide dissipated rapidly after each spray. The concentrations of Copper salts, Copper hydroxide and Copper oxychloride in lettuce plants 10 days after the $1^{\text {st }}$ spray were $23,33.3$ and $36.5 \mathrm{mg} \mathrm{kg}^{-1}$, respectively. While, in the $2^{\text {nd }}$ and $3^{\text {rd }}$ sprays, the values were 30,34 and $31 \mathrm{mg} \mathrm{kg}^{-1}$ and 20,23 and $26 \mathrm{mg} \mathrm{kg}^{-1}$, respectively. 
Table 3. Dissipation of copper compounds residues ( $\mathrm{mg} \mathrm{kg}^{-1} \pm \mathrm{SD}$ ), and pre-harvest intervals (PHI's) on Lettuce plants.

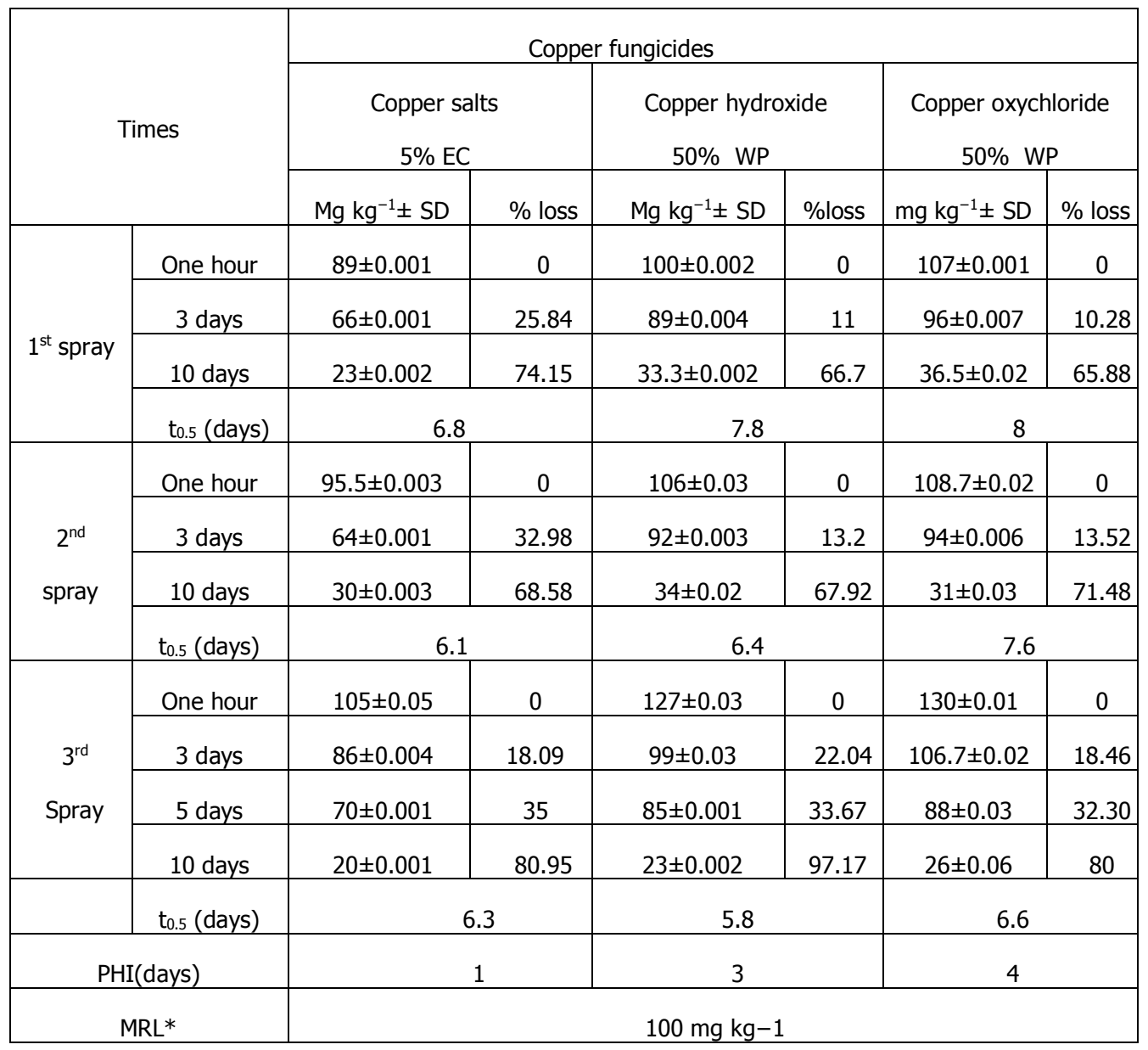

MRL* European Union Pesticides Database 2009

Our results agreed with the results of El-Nahas (2006), as she found residues of copper in cucumber shoot and fruit with different trend, where copper oxychloride recorded the highest amounts, followed by copper hydroxide. McGrath (2013) found the most residue was observed on leaves of lettuce on plants treated with copper sulfate. Copper octanoate left the least amount of residue. Copper oxychloride + copper hydroxide caused much less injury; while copper octanoate caused very little damage. Aikpokpodion et al., (2013) used three levels of copper concentrations at the rate of $1.98,3.96$ and $5.94 \mathrm{~g} \mathrm{Cu} \mathrm{L}^{-1}$ at 15 day intervals. Copper residue in treated plant were higher than control. However, plant treated with 3.96 and $5.94 \mathrm{~g}$ $\mathrm{Cu} \mathrm{L} \mathrm{L}^{-1}$ were significantly higher $(\mathrm{P}<0.05)$ in $\mathrm{Cu}$ residue. Copper residue in plant treated with $1.98,3.96$ and $5.94 \mathrm{~g} \mathrm{Cu} \mathrm{L}^{-1}$ increased 10.06, 28.44 and $33.77 \%$ respectively. They made correlation between copper forms, residue levels and different spray intervals 
The dissipation of the fungicide residues in/on crops depends on environmental conditions, type of application, plant species, dosage, and interval between applications, the relation between the treated surface and its weight and growth stage of the plant surface, in addition to harvest time. European Union Pesticides Database (2009) defined MRL for copper compounds in lettuce plants as $100 \mathrm{mg} \mathrm{kg}^{-1}$. Therefore lettuce could be consumed safely after 1, 3 and 4 days from spray with Copper salts, Copper hydroxide and Copper oxychloride, respectively. It is important to respect the PHI so that the MRL for given crop is not exceeded by following the application rates, number of applications and PHI stated on the label.

\section{REFERENCES}

1. Aikpokpodion, P. E.; L. Lajide and A. F. Aiyesanmi. 2013. Impacts of cu-based fungicide on copper residue and mineral elements distribution in cocoa beans and pods. World J. Agricultural Sciences, 9 (1): 10-16.

2. APHA, A. P. H. A. 2005. National coordinator for health information technology. In136th Annual Meeting (p.18). San Diego. U.S.A.

3. EPA, 2015:http:// www.epa.gov/OCEPA term's

4. European Union Pesticides Database. 2009. http://ec.europa.eu/food/ plant/pesticides/eu-pesticides-database/public/?event=activesubs tance. selection\&language $=\mathrm{EN}(16$ August 2015).

5. FAO/WHO. 1986. Recommended methods of sampling for determination of pesticide residues, vol. VIII, 2nd edn, pt VI.

6. Lebeda, A.; Ryder E.J.; Grube R.; DoleŽalovA I. and KŘIstkovA E. 2007. Lettuce (Asteraceae; Lactuca spp.). In: SINGH R.J. (ed.), Genetic Resources, Chromosome Engineering, and Crop Improvement, Vol. 3, Vegetable Crops. Boca Raton, CRC Press, Tailor and Francis Group: 377-472.

7. McGrath Margaret, G. 2013. Copper fungicides for organic disease management in vegetables.http://cvp.cce.cornell.edu/ submission. php?id=151. Cornell University 2013.

8. Rubatzky V. E. and Yamaguchi M. 1997. World Vegetables. New York, Chapman \& Hall.

9. Schneiderhan, F. J. 1933. The discovery of Bordeaux mixture. Phytopathological Classics, Number 3: 1-25.

10. El-nahas Shereen, E. M. 2006 Bio-residual and non-target activities of certain copper fungicides controlling downy mildew diseases on cucumber.Sc., Fac. of Agric., Ain Shams University., 150pp.

11. Zwieten M. V.; G. Stovold and L. V. Zwieten. 2007. Alternatives to copper for disease control in the Australian organic industry. A report for the Rural Industries Research and Development Corporation. http://www.rirdc.gov.au/ fullreports/index.html 


\section{تأثير متبقى بعض المبيدات الفطريه النحاسيه فى مكافحة مرض البياض الزغبى على الخس}

اسماء محمود القللى' شيرين السيد محمد النحاس' طارق عبد العليم عبد الرحمن '

$$
\text { r - معهد بحوث أمراض النباتات - مركز البحوث الزراعية - الجيزة - مصر . }
$$

تمت در اسة متبقيات بعض المبيدت الفطريه النحاسيه (أوكسى كلورو النحاس ، هيدروكسيد

النحاس و أملاح النحاس المحمله على الأحماض الدهنية) المستخدمه ضد مرض البيــاض الزغبـي

(بريميا لاكتيوكا) في الأوراق. أظهرت النتائج أن جميع المبيدات الفطريه النحاسيه ادت الى وجــود

متبقيات للنحاس في اور اق الخس ، ولكن بكميات مختلفة وفقا لمعدلات استخدامها. و أثنارت النتــائج

إلى أن فترة ماقبل حصاد (PHI) للخس المعامل بالمبيدات النحاسيه المستخدمه فى الدراسه كانت )

r ، ـ يوم من المعامله بأملاح النحاس المحمله على الاحماض الدهنية، اوكسى كلورو النحسـاس ،

هيدروكسيد النحاس على التزتيب. 